BLS 34, No 1 2008. DOI: http://dx.doi.org/10.3765/bls.v34i1.3557 (published by the Berkeley Linguistics Society and the Linguistic Society of America)

\title{
Phonetics vs. Phonology in Loanword Adaptation: Revisiting the Role of the Bilingual ${ }^{1}$
}

\author{
CHARLES B. CHANG \\ University of California, Berkeley
}

\section{Introduction}

In recent studies of loanword adaptation, two main sides have emerged. On the one hand, phonetic accounts emphasize the influence of low-level perceptual factors in the mapping of source language (L2) forms to receptor language (L1) forms. On the other hand, phonological accounts contend that foreign words are incorporated into a language on the basis of phonological similarity between L1 and L2 phonemic categories by bilinguals with access to the phonology of both L1 and L2. In this paper, evidence from Burmese is presented in favor of an intermediate model incorporating both language-independent phonetics and language-particular phonology.

The paper is organized as follows. Section 1 reviews some key studies in the ongoing debate regarding the relative influence of phonetics vs. phonology in loanword adaptation. Section 2 provides background on Burmese phonology, with special attention to phonological differences from English. Section 3 presents examples of phonological scansion and phonetic scansion in the adaptation of English loanwords in Burmese. Finally, Sections 4 and 5 discuss the results and summarize the conclusions.

\section{Phonetics vs. Phonology in Loanword Adaptation}

Researchers endorsing a "phonetic approximation" view of loanword adaptation basically posit that perceptual (and, thereby, acoustic) similarity is responsible for the way L2 forms are mapped onto L1 forms. Though some studies may imply otherwise, phonology is not irrelevant under this view. On the contrary, it is

\footnotetext{
${ }^{1}$ I am indebted to Larry Hyman, Mathias Jenny, Michael Kenstowicz, Darlene LaCharité, Javier Martín-González, Lynn Nichols, Donca Steriade, Bert Vaux, Ingyin Zaw, Jie Zhang, and audiences at SEALS XVII, BLS 34, and PLC 32 for comments, feedback, and data that have greatly improved this paper. This work was supported by a grant from the Harvard College Research Program, a Jacob K. Javits Fellowship, and a National Science Foundation Graduate Research Fellowship. Any remaining errors are mine.
} 
Charles B. Chang

precisely the perceptual biases from the L1 phonological system that are generally thought to result in unfaithful perception of L2 forms. In a nutshell, under this view transformations occur in loanwords vis-à-vis the original L2 forms because borrowers are non-native speakers of the L2 who hear the L2 forms unreliably.

In an early study representative of the phonetic approximation view, Silverman (1992) advances a two-tiered model of adaptation in which the first level involves phonetic scansion of the L2 output. He assumes that "the input to loanword phonology is merely a superficial non-linguistic acoustic signal" (1992:289), which is parsed into segments on the first level and mapped onto phonemes of the native L1 on the basis of acoustic similarity. On the second level, L1 phonological constraints are imposed upon the input, and Universal Grammar principles may apply. A notable claim of this model is that phonological knowledge of L2 plays no role in adaptation. Evidence from loanwords in Cantonese suggests that Cantonese speakers are unable to access the source phonological representations of incoming loanwords; thus, the role of the bilingual in loanword adaptation is said to be minimal.

The strongest version of the phonetic approximation view is developed in a later series of papers by Peperkamp and her colleagues (cf. Peperkamp and Dupoux 2003, Vendelin and Peperkamp 2004, Peperkamp 2005), who argue that not just some, but all transformations in loanwords result from unfaithful L2 perception (and, thus, that these transformations are phonetic in nature). Drawing parallels between the loanword literature and the cross-linguistic speech perception literature, Peperkamp argues that "loanword adaptations are basically phonetic rather than phonological in nature, and originate in the process of phonetic decoding during speech perception" (2005:350), though she acknowledges that this hypothesis is "a strong one that might be overly simplistic" (2005:349).

In contrast, the "phonological approximation" view of loanword adaptation contends that L2-to-L1 mapping occurs on the basis of phonological distance, rather than phonetic distance between categories: a foreign L2 segment is replaced by the L1 segment that is the closest phonologically (in terms of features), which is not necessarily the segment that is the closest perceptually. The most recent proponents of this view are Paradis and LaCharité, who in series of papers (cf. Paradis and LaCharité 1997, 2008; LaCharité and Paradis 2005) argue that bilinguals, who have access to the phonology of L2, are the ones chiefly responsible for introducing borrowings into a language, and that since the bilingual borrower knows the underlying representation for an L2 form, it is this phonemic representation that constitutes the input to L1. This fact lies behind much of the otherwise inexplicable data they provide on segmental adaptation.

LaCharité and Paradis (2005) point out several cases of loanword adaptation where an L2 segment is replaced by the phonologically closest L1 segment instead of the phonetically closest one (independently identified in speech perception and language acquisition studies). For example, English voiced stops, typically realized in initial position with no voicing during closure and simply a shortlag voice onset time (VOT), are closer phonetically to Spanish voiceless stops 


\section{Phonetics vs. Phonology in Loanword Adaptation}

(unaspirated with short-lag VOT) than to Spanish voiced stops (strongly prevoiced with negative VOT). Therefore, if English voiced stops in loanwords were adapted phonetically, one would expect them to be mapped to Spanish voiceless stops, but on the contrary, they are mapped to the voiced stops, the phonologically closest category. The adaptation of English rhotics in Japanese and the adaptation of the English high lax vowels /I, $\mathrm{U} /$ in a number of languages (e.g. Mexican Spanish, Parisian French) show a similar pattern.

This evidence suggests that what gives rise to segmental adaptations are not relationships of phonetic similarity, but relationships of phonological similarity. The extremely low rate of deletion present in the loanword corpora examined by LaCharité and Paradis - much lower than one would predict if faulty L2 perception were responsible for the changes made in loanwords - further supports the idea that borrowers' L2 perception is, in fact, not faulty at all.

\section{A Primer on Burmese Phonology}

\subsection{Consonant, Vowel, and Tone Inventories}

The segment inventories of Burmese are given in (1) and (2), where strictly allophonic segments have been placed in parentheses.

(1) Burmese consonant inventory

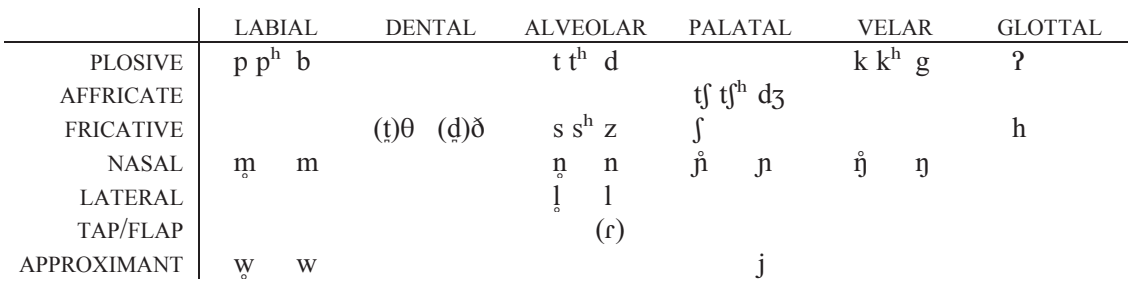

(2)

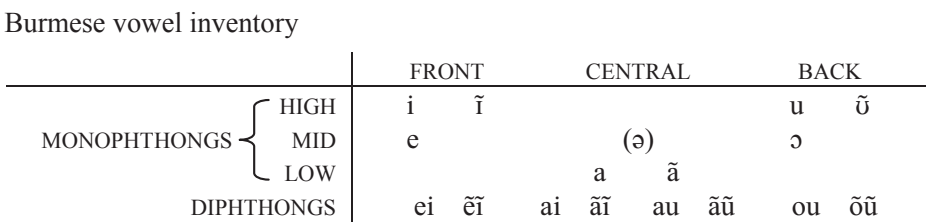

Notable consonantal gaps in comparison to English are the lack of /f, v, I, 3/. With respect to vowels, mid nasal vowels and /æ, oI/ do not occur. Other English vowels missing from Burmese, such as the lax vowels /I, $\varepsilon, v /$, have close correspondents in Burmese vowel allophones not included in (2).

Burmese is a tone language, where differences between tones have to do not only with pitch, but also duration, intensity, phonation, and vowel quality (Green 2005). By most accounts (e.g. Wheatley 1987, Green 2005), there are four distinct tones: low, high, creaky, and a "checked" or glottal tone with the general features of creaky tone followed by glottal stop (cf. 3). The tone on schwa is neutral. 
Charles B. Chang

(3) Burmese tone inventory

\begin{tabular}{ccc}
\hline TONE & TRANSCRIPTION & CHARACTERISTICS \\
\hline low & à & medium duration, low intensity, low/rising pitch \\
high & á & long duration, high intensity, high/falling pitch, often breathy \\
creaky & $\underset{\text { a }}{\text { a? }}$ & short duration, high intensity, high/falling pitch, creaky \\
glottal & very short duration, high pitch, sharp glottal closure \\
\hline
\end{tabular}

\subsection{Syllable Structure and Phonotactics}

The basic Burmese syllable structure is $\mathrm{C}_{1}\left(\mathrm{C}_{2}\right) \mathrm{V}(\mathrm{V})\left(\mathrm{C}_{3}\right)$, where $\mathrm{C}_{2}$ is an approximant. The rhyme minimally contains a monophthongal nucleus, and may also contain a diphthong. An optional coda $\mathrm{C}_{3}$ is limited to the glottal stop occurring with glottal tone. Several phonotactic restrictions apply to this basic structure. First, the glide / $\mathrm{j} /$ only occurs after labials; clusters such as $* / \mathrm{tj}, \mathrm{kj} /$ are ill-formed (Green 2005). Second, the diphthongs /ai, au/ only occur before coda glottal stop. Third, /o/ does not occur with a glottal coda (Cornyn 1944), while lax vowel allophones $[\mathrm{I}, \varepsilon, U, \Lambda]$ only occur with a glottal coda, or else nasalized (except $[\varepsilon]$ ). In addition, the configuration of a nasalized vowel followed by a coda glottal is disallowed (ibid.). Finally, a syllable with a schwa cannot stand on its own and is always bound to a following major syllable with a full vowel (ibid.).

\section{Loanword Adaptation in Burmese: Phonological or Phonetic?}

This study focuses on a corpus of 278 adaptations comprising 193 established loanwords and 46 non-words gathered from one main Burmese-English bilingual consultant, as well as 39 adaptations cited by Wheatley (1987), Win (1998), and Green (2005). Non-word adaptations were based upon aural input. Examples from Wheatley, Win, or Green are marked as 'Wh', 'Wi', or 'G', respectively.

\subsection{Phonological Scansion of the Input}

In contrast to the phonetic mapping of segments predicted by Silverman (1992), English input is scanned phonologically in Burmese loanword adaptation. This level of phonological scansion is apparent in the adaptation of English allophones corresponding to Burmese phonemes and the adaptation of English phonemes corresponding to Burmese allophones. For example, English allophonically aspirated $\left[\mathrm{p}^{\mathrm{h}}\right]$ is consistently adapted with Burmese /p/ (cf. 4) rather than Burmese $/ \mathrm{p}^{\mathrm{h}} /$, which is used instead to represent English [f] (cf. 5).

(4)

\begin{tabular}{|c|c|c|}
\hline a. penguin & $>$ & [pĩ̀.gwì̀] \\
\hline plastic & $>$ & [pə.la?.sə.tı?] \\
\hline Japan & $>$ & [dzə.pã̀] \\
\hline champagne & $>$ & 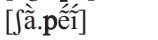 \\
\hline file & $>$ & [phà̃̀ì $]$ \\
\hline film & $>$ & {$\left[\mathrm{p}^{\mathrm{h}}\right.$ ○.|İ̀] } \\
\hline Finland & $>$ & [p $\mathrm{p}^{\mathrm{h}} \mathrm{i} .1 \mathrm{a}$ ] \\
\hline phone & $>$ & [p $\left.\mathrm{p}^{\mathrm{h}} \tilde{o} \tilde{u}\right]$ \\
\hline
\end{tabular}

\begin{tabular}{|c|c|c|}
\hline Poland & $>$ & [pòù.lã̃] \\
\hline police & $>$ & [pə.lei?] \\
\hline computer & $>$ & [kồu ù.pjù.tà] \\
\hline ball pen & $>$ & [bó.pĩ̃] \\
\hline four & $>$ & [p óú] \\
\hline feeling & $>$ & {$\left[\mathrm{p}^{\mathrm{h}} \mathrm{i} .1 \mathrm{\tilde {I }}\right]$} \\
\hline Philippines & $>$ & [p $\mathrm{p}^{\mathrm{h}}$ i.lı?.pã̀ì $]$ \\
\hline coffee & $>$ & [kò.p. $\left.\mathrm{p}^{\mathrm{h}} \mathrm{i}\right]$ \\
\hline
\end{tabular}




\section{Phonetics vs. Phonology in Loanword Adaptation}

In other words, the adaptation of English [ $\left.\mathrm{p}^{\mathrm{h}}\right]$ occurs on the phonemic level, not on an allophonic level; thus, the phone $\left[\mathrm{p}^{\mathrm{h}}\right]$, as an allophone of the phoneme $/ \mathrm{p} /$, is adapted as Burmese $/ \mathrm{p} /$. The adaptation of aspirated stops at other places of articulation is similar, with both alveolars and velars being adapted with the Burmese unaspirated series nearly all of the time (cf. 6). ${ }^{2}$

\begin{tabular}{|c|c|c|c|c|}
\hline INPUT & $n$ & UNASPIRATED & ASPIRATED & $\%$ UNASPIRATED \\
\hline$\left[\mathrm{p}^{\mathrm{h}}\right]$ & 21 & 21 & 0 & $100.0 \%$ \\
\hline$\left[\mathrm{t}^{\mathrm{h}}\right]$ & 17 & 15 & 2 & $88.2 \%$ \\
\hline$\left[\mathrm{k}^{\mathrm{h}}\right]$ & 36 & 34 & 2 & $94.4 \%$ \\
\hline
\end{tabular}

English [ $\mathrm{r}]$ is also adapted on the phonemic level. As an allophone of English /d/, [r] is rendered as Burmese /d/ (cf. 7), which prevents English [r] from falling together with a different segment that is adapted with Burmese [r] - namely, English onset $/ \mathrm{x} /$ (cf. 8). This mapping pattern, too, is quite consistent and is by far the dominant pattern in the corpus (cf. 9). ${ }^{3}$

$$
\text { a. powder }>\text { [pã̀ù̃.dà] }
$$

c. $\operatorname{soda}$

$>\quad\left[\mathrm{s}^{\mathrm{h}}\right.$ òùdà $]$

b. radio

d. video

$>$ [jè̀i.dì.jò̀ $]$

(8)

\begin{tabular}{|c|c|c|}
\hline a. rifle & $>$ & [rã̀ì.ph è] \\
\hline steering & $>$ & [sə.tì.jà..ã̀ì] \\
\hline Victoria & $>$ & [wi.tòù.ri.ja] \\
\hline g. brake & $>$ & [bə.rei?] \\
\hline
\end{tabular}

b. rubber

d. director

f. cigarette

h. drum

$>$ [bì.dì.jò]

Corpus figures for adaptations of flapped /d/

\begin{tabular}{ccccc}
\hline INPUT & $n$ & $\#[\mathrm{~d}]$ & $\#[\mathrm{r}]$ & $\%[\mathrm{~d}]$ \\
\hline$[\mathrm{r}]$ & 10 & 8 & 1 & $80.0 \%$ \\
\hline
\end{tabular}

In addition, English contrasts that constitute allophony in Burmese are faithfully adapted, not disregarded. In particular, the tense/lax vowel distinction is generally maintained in loanwords despite the fact that neither vowel tenseness nor length is phonemic in Burmese. Tense vowels are adapted as tense (cf. 10), while lax vowel quality is achieved through the use of glottal tone, whose concomitant glottal coda has the effect of laxing/centralizing the host vowel (cf. 11).
a. $C D$
[sì.dì]
c. B.A.
[bì.?è̀]
b. university
[jù.nì.bà.sì.tì]
d. Coca-Cola $>$ [kò̀u.kà.kòù.là $]$

\footnotetext{
${ }^{2}$ Note that this is unlikely to be due to a salient difference in aspiration between Burmese and English. Unlike Mandarin aspirated plosives, which are aspirated on average about $40 \mathrm{~ms}$ more than English voiceless plosives (cf. Wu and Lin 1989, Lisker and Abramson 1964), Burmese aspirated plosives tend to be aspirated only about $10 \mathrm{~ms}$ more than English voiceless plosives.

${ }^{3}$ See Paradis and LaCharité (1997) and LaCharité and Paradis (2005) for arguments against assuming that this mapping arises from L2 orthographic cues.
} 
Charles B. Chang

\begin{tabular}{|c|c|c|c|}
\hline a. & Living & $>$ & [lı?.bÍ̃ \\
\hline c. & B.Sc. & $>$ & [bì.Pع?.sì] \\
\hline e. & jacket & $>$ & [d $3 \varepsilon ? . \mathrm{k} \varepsilon ?]$ \\
\hline g. & $b u s+c a r$ & $>$ & [bムP.sə.ká] \\
\hline
\end{tabular}

\begin{tabular}{|c|c|c|}
\hline City Mart & $>$ & [sı?.tì.ma?] \\
\hline Jessica & $>$ & [dze?.sì.kà] \\
\hline Craddock & $>$ & 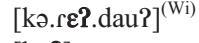 \\
\hline 'vood' $([\mathrm{v}])$ & $>$ & [bu?] \\
\hline
\end{tabular}

Though the pattern of adapting English lax vowels as Burmese lax vowels is not as robust as the non-preservation of allophonic aspiration, it is still the dominant pattern in the corpus. (12) shows that when only stressed input lax vowels are counted, Burmese clearly favors output lax vowels; if the counts are expanded to include all vowels, the results favor lax adaptations even more strongly.

\begin{tabular}{ccccc}
\multicolumn{6}{c}{ Corpus figures for adaptations of stressed lax vowel phonemes } \\
\hline INPUT & $n$ & LAX & TENSE & \% LAX \\
\hline $\mathrm{V}_{\text {[-tense] }}$ & 135 & 90 & 45 & $66.7 \%$ \\
{$[\mathrm{I}]$} & 63 & 41 & 22 & $65.1 \%$ \\
{$[\varepsilon]$} & 32 & 22 & 10 & $68.8 \%$ \\
{$[æ]$} & 23 & 17 & 6 & $73.9 \%$ \\
{$[\Lambda]$} & 15 & 8 & 7 & $53.3 \%$ \\
{$[\mathrm{U}]$} & 2 & 2 & 0 & $100.0 \%$ \\
\hline
\end{tabular}

Thus, the non-adaptation of L2 allophonic details that are phonemic in L1 and the adaptation of L2 phonemic details that are only allophonic in L1 suggest that what the borrower of an L2 word attends to is information that is phonemic in L2. This strategy is shown in (13) for the case of the voiceless labials.

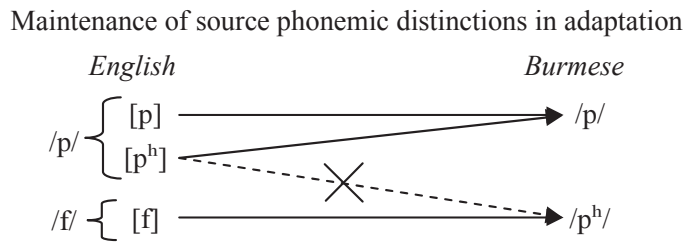

It was observed above that Burmese $[\mathrm{r}]$ is used to adapt English onset / $\mathrm{I} /$ (cf. 8). In actuality, this is not the only segment that corresponds to $/ \mathrm{I} /$ in loanword adaptations; Burmese [j] also occurs (cf. 14) and is in fact the prototypical substitution made for $/ \mathrm{I} /$ in older loanwords and in the L2 speech of Burmese learners of English (cf. Win 1998). The corpus indicates, however, that [r] now occurs more often than [j]. (15) shows that when only the most frequent variants of loanwords are counted, $[\mathrm{r}]$ is slightly favored as the adaptation of $/ \mathrm{x} /$; if the counts are expanded to include all variants, [r] emerges as the clearly favored adaptation, as nearly all relevant loanwords occur with a [r]-variant as a possible form.
(14) a. radio
$>\quad$ [jè̀idì.jòù]
c. Russia
$>\quad$ [ju.fá]
e. April
$>$ [?è̀.pjì $]$
b. rum
d. crown
$>$ [jã̀]
f. Andrew $>$ [จั่do.jú]


Phonetics vs. Phonology in Loanword Adaptation

Corpus figures for most frequent adaptations of onset /I/
\begin{tabular}{ccccc}
\hline INPUT & $n$ & $\#[\mathrm{r}]$ & $\#[\mathrm{j}]$ & $\%[\mathrm{r}]$ \\
\hline$[\mathrm{I}]$ & 37 & 20 & 17 & $54.1 \%$ \\
\hline
\end{tabular}

Thus, in this case of variation in adaptation as well there is movement towards a segmental mapping strategy that avoids phonological neutralization (here, between $/ \mathrm{x} /$ and $/ \mathrm{j} /$ ), as schematized in (13). In newer $/ \mathrm{I} /$-ful loans, the adaptation of $/ \mathrm{I} /$ chosen is the one not already associated with an L2 segment - namely, [r]. In this way, [r] appears to have taken over as the prototypical adaptation of $/ \mathrm{I} /$.

A final example of the influence of phonological knowledge is the adaptation of onset /nj/ clusters. An item like New York, adapted as [nə.jú.jau?] rather than *[nú.jau?], shows that borrowers correctly interpret /nj/ as a cluster, even though the palatal nasal $/ \mathrm{n} /$ would arguably serve as the closest perceptual substitution.

\subsection{Phonetic Scansion of the Input}

Clearly, then, a level of phonological scansion must be involved in the adaptation of English loanwords in Burmese. However, some adaptations show that borrowers also pick up on phonetic details that are phonemic in neither English nor Burmese. For instance, the phonetically voiceless [I.] interval that occurs after voiceless aspirated plosives in English $\sigma$ [TR clusters appears to influence the percept of the preceding aspirated plosive such that it is often adapted as aspirated in only this environment (cf. 16a-c), in stark contrast to the otherwise general disregard for aspiration on voiceless stops seen above in (4).

$$
\begin{aligned}
& \text { a. Christ }>\left[\mathrm{k}^{\mathrm{h}} \text { ə.กI? }\right] \quad \text { b. cream }>\left[\mathrm{k}^{\mathbf{h}} \text { ə.jì }\right]
\end{aligned}
$$

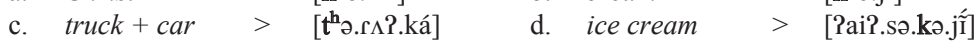

Note also the striking contrast between (16b) and (16d), both of which involve adaptations of the word cream. In (16b), / $\mathrm{k} /$ is word-initial and aspirated, devoicing much of the following $/ \mathrm{x} /$, and this leads to $/ \mathrm{k} /$ being adapted as aspirated. In (16d), however, $/ \mathrm{k} /$ is preceded by $/ \mathrm{s} /$, forming a cluster which is well-known in English for containing the unaspirated allophones of the voiceless plosives. Here the input likely contains reduced or no aspiration and, accordingly, reduced or no devoicing of $/ \mathrm{x} /$; it follows that the plosive here is adapted as unaspirated per the usual pattern. Borrowers thus appear capable of distinguishing phonologically identical sequences on the basis of phonetic differences between them.

Another example of attention to subphonemic detail involves the adaptation of coda clusters comprising a nasal and obstruent. Given that coda nasals are normally adapted via vowel nasalization, the standard strategy of using glottal tone to adapt coda obstruents cannot be used here since nasal vowels are incompatible with coda glottals (cf. §2.2). The tone assigned to the nasal vowel must therefore be one of the other three tones. If the tone were assigned randomly, we would expect it to surface roughly $33 \%$ of the time as high, $33 \%$ of the time as low, and $33 \%$ of the time as creaky. What we find instead is that creaky tone is the most 
Charles B. Chang

frequent adaptation (e.g. 17), reflecting the laryngealization that occurs in this environment in anticipation of the final voiceless closure, which is often made

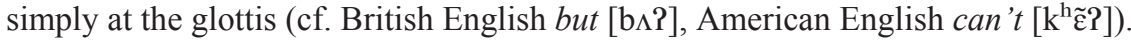
However, this pattern only occurs when the final obstruents are voiceless. When they are voiced, the tone assigned to the syllable is never creaky (cf. 18).

a. Sphinx

$>\quad\left[\right.$ sə.p. $\left.{ }^{h} \tilde{\underline{I}}\right]$

b. count

[kãã̃ $]$

(18) Corpus figures for tones assigned to syllables with complex codas

\begin{tabular}{ccccc}
\hline INPUT & $n$ & CREAKY & NON-CREAKY & \% CREAKY \\
\hline $\mathrm{NC}(\mathrm{C})]_{\sigma}$ & 7 & 4 & 3 & $57.1 \%$ \\
$\mathrm{NC}(\mathrm{C})]_{\sigma}$ & 6 & 0 & 6 & $0.0 \%$ \\
\hline
\end{tabular}

Thus, borrowers do not treat all $\mathrm{NC}(\mathrm{C})$ clusters the same. Creaky tone assignment depends not only on whether there are coda obstruents, but also on whether laryngealization occurs. Borrowers clearly discriminate between syllable structures that are phonologically identical, but phonetically different, indicating once again that L2 scansion in loanword adaptation cannot be strictly phonological.

A final example of phonetic differentiation between phonologically identical structures is the adaptation of medial consonant clusters, which does not always follow the pattern appropriate for the input syllabification. On the one hand, medial onset clusters are resolved like initial onset clusters: the constituent consonants are preserved, through schwa epenthesis if necessary (e.g. 19a-b vs. $19 \mathrm{c}-\mathrm{d})$. A corpus investigation further shows that medial onset clusters are always resolved in this way (cf. 20).

a. Scott

c. biscuit

$\begin{array}{ll}> & {[\text { sə.kə] }]} \\ > & {[\text { bIP.sə.kı? }]}\end{array}$

b. club

d. cyclone

$\begin{array}{ll}> & {[\mathrm{k} ə .1 \Lambda ?]} \\ > & {[\mathrm{s} \text { hã̃î.kə.lốú }]^{(\mathrm{G})}}\end{array}$

Corpus figures for adaptations of medial onset clusters

\begin{tabular}{ccccc}
\hline INPUT & $n$ & $\#$ CC / Cə.C & $\#$ 2.C / Ø.C & $\%$ CC / Cə.C \\
\hline$\ldots$ \$CC $\ldots$ & 20 & 20 & 0 & $100.0 \%$ \\
\hline
\end{tabular}

On the other hand, medial heterosyllabic clusters are treated in one of two ways. They are either resolved like onset clusters (e.g. 21a-b) or like a sequence of coda and onset, with codas normally being either debuccalized or deleted (e.g. 21c-d).

$$
\begin{aligned}
& \text { a. Maz.da }>\text { [mà.zə.dà }] \\
& \text { c. Jet.son }>\left[\mathrm{d} z \varepsilon ? . \mathrm{s}^{\mathrm{h}} \mathrm{I}\right]
\end{aligned}
$$

b. helicop.ter $>$ [hè.lì.kõ.po.tà ${ }^{(\mathrm{Wh})}$

d. Oc.tober $>$ [?au?.tòu.bà]

This variation in adaptation strategy is not random, however. A pattern emerges from the corpus whereby some heterosyllabic clusters are generally adapted like onset clusters, while other heterosyllabic clusters are always resolved as codaonset sequences, these latter cluster types being [t.s], [k.t], and [k.s]. (22) indicates that heterosyllabic clusters are resolved as onset clusters about one-third of 


\section{Phonetics vs. Phonology in Loanword Adaptation}

the time in the corpus, but if the data are separated by cluster type, it turns out that $[\mathrm{t} . \mathrm{s}] /[\mathrm{k} . \mathrm{t}] /[\mathrm{k} . \mathrm{s}]$ clusters are never resolved like onset clusters, while all other clusters are resolved like onset clusters nearly $80 \%$ of the time.

\begin{tabular}{|c|c|c|c|c|}
\hline INPUT & $n$ & \# CC / Cə.C & $\#$ \#.C / Ø.C & $\%$ CC / Cə.C \\
\hline ...C.C... & 19 & 7 & 12 & $36.8 \%$ \\
\hline [p.t] & 3 & 2 & 1 & \\
\hline [p.s] & 2 & 1 & 1 & \\
\hline$[\theta .1]$ & 1 & 1 & 0 & \\
\hline [t.s] & 3 & $\mathbf{0}$ & 3 & \\
\hline [t.l] & 1 & 1 & 0 & \\
\hline [z.d] & 1 & 1 & 0 & \\
\hline [Z.II] & 1 & 1 & 0 & \\
\hline [k.t] & 5 & $\mathbf{0}$ & 5 & \\
\hline$[\mathrm{k} . \mathrm{s}]$ & 2 & $\mathbf{0}$ & 2 & \\
\hline
\end{tabular}

Thus, once again phonologically identical syllable structures are treated differently on the basis of phonetic differences between them. In this case, coda [t] preceding $[\mathrm{s}]$ and coda $[\mathrm{k}]$ are debuccalized, while all other coda-onset sequences are adapted via epenthesis and resyllabification. As for why these particular codas should go to [?] while other codas are preserved, the distinction is most likely one of relative perceptual salience (cf. Shinohara 2006). There are a couple of reasons why the $[\mathrm{t}]$ in $[\mathrm{t} . \mathrm{s}]$ and the $[\mathrm{k}]$ in $[\mathrm{k} . \mathrm{t}]$ and $[\mathrm{k} . \mathrm{s}]$ would be less salient than the codas in the other clusters seen in (22). First, among English oral stops the velar stop is articulated the farthest back in the vocal tract, allowing obstruents at basically any other place of articulation to obscure its constriction when gestures overlap in real time; a velar release cannot be heard when it is "covered up" by a more forward alveolar closure, for instance. Second, the juxtaposition of these stops against perhaps the most perceptually salient segment of all, the highfrequency sibilant [s], is also likely to have the effect of obscuring or drawing attention away from release cues of the stop, especially when the release interval is overlapped with the beginning of the strident interval of [s]; this is especially so in the case of [t.s] since the two segments share the same place of articulation.

\section{Discussion}

To summarize, the adaptation of English loanwords in Burmese appears to involve both phonological and phonetic scansion of the L2 input. On the one hand, the faithful adaptation of distinctive L2 information that is non-distinctive in L1 and the abstraction away from non-distinctive L2 information that is distinctive in L1 suggest that L2 phonological knowledge is utilized in L2-to-L1 mapping. On the other hand, the impact on adaptations of phonetic details that are distinctive in neither L1 nor L2 suggests that phonetics is considered as well.

The phonological nature of aspects of English loanword adaptation in Burmese suggests that borrowers are indeed bilingual in Burmese and English to 
Charles B. Chang

some degree, but the question remains: how bilingual are they? Over a nearly 100-year period of British colonial rule, exposure to English would have been commonplace, and some sources suggest that in the recent past bilingualism was not uncommon, at least among the formally educated:

\begin{abstract}
In the past, Burma's educated class was nearly bilingual, but as a result of several decades of neglect of English language training, fewer younger people speak or understand English well...English and Burmese are widely spoken and used for official purposes...English fluency is not universal. (USDOS 1995)
\end{abstract}

While the country was still under British colonial rule in the 1920s and 1930s, an upsurge in nationalistic sentiment led to the increasing use of Burmese instead of English in education and public life. However, by the 1980s there had been a shift back to the use of English. English is widely used as a teaching medium in schools and is the only language used at university level. (Baker and Jones 1998:379-380)

However, while English is still used by the government and educated people, it is no longer the primary language of instruction in higher education (Thein 2004), and consequently the extent of bilingualism seems to have declined significantly over the last 20-30 years:

Burmese over the age of 40 , particularly those over 65 years of age, are generally welleducated, but the lack of investment in education by the military regime and the repeated closing of Burmese universities over the past 18 years have taken a toll on the country's young. Most in the 15-39 year old demographic group lack technical skills and English proficiency. Many older educated Burmese studied English in mission schools during the British colonial and early independence period. The military nationalized schools in 1964 and discouraged the teaching of English in favor of Burmese. (USDOS 2007)

Given that English loanwords appear to have been borrowed into Burmese at different times, it is likely that the borrowers of these words were not uniform in their English proficiency. This potential variation in the borrowers' degree of bilingualism in English may underlie the mixed phonetic-and-phonological nature of the loanword adaptations examined in this study, or the mixed strategies might simply result from a lower level of bilingualism: speakers are somewhat proficient in English and apply an incomplete knowledge of English phonology to the adaptation of English loanwords. Note that this situation contrasts with the case of a language adapting either phonetically or phonologically depending on the L2 (e.g. French and German front rounded vowels in Japanese, cf. Dohlus 2005); it also contrasts with the case of a language adapting L2 borrowings phonologically at one point in time and phonetically at another point in time (e.g. Chinese borrowings in Japanese during a period of high vs. low bilingualism, cf. Heffernan 2007). The latter scenario in particular does not accurately characterize the Burmese facts, since it is not the case that some loanwords are adapted phonologically, while others are phonetically. Rather, the evidence suggests that attention is paid to phonology and phonetics at the same time, even in the same loan- 


\section{Phonetics vs. Phonology in Loanword Adaptation}

words (e.g. count $>$ [kãa ũ ], in which allophonic aspiration is disregarded, but allophonic laryngealization is adapted faithfully).

The present proposal is that the mixed adaptation situation in Burmese arises from an intermediate state of bilingualism in which borrowers have some, but not full knowledge of the phonology of L2, and therefore still attend to phonetic details of L2 while applying the phonological knowledge that they do have. Alternatively, it may be that the borrowers have full phonological knowledge of L2, but that they nonetheless maintain active phonetic awareness of L2. In this case, the input to loanword adaptation would be "enriched" in the way proposed by Kang (2008:114), who argues that "the phonological representation that the interlanguage mapping refers to should contain phonetic details that are considered non-contrastive in L1 and at the same time should somehow acknowledge the privileged status of contrastive features". In short, the fact that bilingual borrowers can adapt loanwords phonologically may not entail that they will.

\section{Conclusion}

Taken together, the findings in this study suggest that a model of loanword adaptation incorporating both phonetics and phonology is the most empirically sound. While loanword adaptations are indeed influenced by phonetic details of the input, bilinguals play a leading role in adaptation, allowing the phonology of L2 to have a profound effect on loanword adaptations in L1. However, the way in which loanwords are adapted is affected not only by the timing of bilingualism with respect to the timing of borrowing, but also by the degree of bilingualism among potential borrowers. In the case of Burmese, it appears that borrowers with an incomplete knowledge of the L2 phonology may be responsible for the mixed nature of English loanword adaptations, which show the influence of both phonological and phonetic considerations.

\section{References}

Baker, Colin, and Sylvia Prys Jones. 1998. Encyclopedia of Bilingualism and Bilingual Education. Clevedon, UK: Multilingual Matters Ltd.

Dohlus, Katrin. 2005. Phonetics or Phonology: Asymmetries in Loanword Adaptations - French and German Mid Front Rounded Vowels in Japanese. ZAS Papers in Linguistics 42:117-135.

Green, Antony D. 2005. Word, Foot, and Syllable Structure in Burmese. In J. Watkins, ed., Studies in Burmese Linguistics, 1-25. Canberra, Australia: Pacific Linguistics.

Heffernan, Kevin. 2007. The Role of Phonemic Contrast in the Formation of Sino-Japanese. Journal of East Asian Linguistics 16(2):61-86.

Kang, Yoonjung. 2008. Interlanguage Segmental Mapping as Evidence for the Nature of Lexical Representation. Language and Linguistics Compass 2(1):103-118. 
Charles B. Chang

LaCharité, Darlene, and Carole Paradis. 2005. Category Preservation and Proximity versus Phonetic Approximation in Loanword Adaptation. Linguistic Inquiry 36(2):223-258.

Lisker, Leigh, and Arthur Abramson. 1964. A Cross-Language Study of Voicing in Initial Stops: Acoustical Measurements. Word 20(3):384-422.

Paradis, Carole, and Darlene LaCharité. 1997. Preservation and Minimality in Loanword Adaptation. Journal of Linguistics 33(2):379-430.

Paradis, Carole, and Darlene LaCharité. 2008. Apparent Phonetic Approximation: English Loanwords in Old Quebec French. Journal of Linguistics 44(1):87-128.

Peperkamp, Sharon. 2005. A Psycholinguistic Theory of Loanword Adaptations. In M. Ettlinger et al., eds., Proceedings of the $30^{\text {th }}$ Annual Meeting of the Berkeley Linguistics Society, 341-352.

Peperkamp, Sharon, and Emmanuel Dupoux. 2003. Reinterpreting Loanword Adaptations: The Role of Perception. In M. J. Solé et al., eds., Proceedings of the $15^{\text {th }}$ International Congress of Phonetic Sciences, 367-370.

Shinohara, Shigeko. 2006. Perceptual Effects in Final Cluster Reduction Patterns. Lingua 116(7):1046-1078.

Silverman, Daniel. 1992. Multiple Scansions in Loanword Phonology: Evidence from Cantonese. Phonology 9(2):298-328.

Thein, Myat. 2004. Economic Development of Myanmar. Singapore: Institute of Southeast Asian Studies.

U.S. Department of State (USDOS). 1995. Country Commercial Guide: Burma (Myanmar). Yangon, Myanmar: U.S. Embassy.

U.S. Department of State (USDOS). 2007. 2007 Investment Climate Statement Burma. Washington, DC: Bureau of Economic and Business Affairs.

Vendelin, Inga, and Sharon Peperkamp. 2004. Evidence for Phonetic Adaptation of Loanwords: An Experimental Study. In Actes des Journées d'Etudes Linguistiques de l'Université de Nantes, 129-131.

Wheatley, Julian K. 1987. Burmese. In B. Comrie, ed., The World's Major Languages, 834-854. New York: Oxford University Press.

Win, Than Than. 1998. Burmese-English Accent: Description, Causes, and Consequences. Ph.D. diss., Northern Illinois University.

Wu, Zongji, and Canmao Lin. 1989. Shi Yan Yu Yin Xue Gai Yao (实验语音学 概要). Beijing: Higher Education Press.

Charles B. Chang

University of California, Berkeley

Department of Linguistics

1203 Dwinelle Hall

Berkeley, CA 94720-2650

cbchang@post.harvard.edu 